the juvenile court, the divorce court's disposition would have to yield. Otherwise the state's paramount interest as super-guardian could be defeated. In other words, if the minor truly comes within Welfare and Institutions Code section 700 so that his health, safety or morals are jeopardized, the exercise of jurisdiction by the juvenile court will probably nullify existing or subsequent custody awards of guardianship appointments contrary to the juvenile court order as long as the child remains a ward of the court. ${ }^{117}$

Of course, mere dissatisfaction with a guardianship or custody order does not empower a parent or other interested person to ask the juvenile court to make a different determination. The overriding jurisdiction of the juvenile court is to be exercised only when the child's welfare is threatened by those serious evils enumerated in section 700 which the court was created to combat. "The purpose of the Juvenile Court Law is not the adjustment of parental disputes concerning the care and education of a minor. Those matters are to be settled in a court of equity where the parents are the actual parties."118

\title{
Adolph Moskovitz*
}

\section{THE PAYMENT OF TAXES REQUIREMENT IN ADVERSE POSSESSION STATUTES}

Although the history of adverse possession as a statutory means of perfecting title to land dates back to the 12 th century, ${ }^{1}$ the requirement that the claimant must have paid all taxes on the land during the statutory period is a recent development. ${ }^{2}$ The first jurisdiction to establish the requirement was Mlinois in $1872 .^{3}$ Geographically, the western states predominate in the group, indicating that the battle against "squatters" in the range country may have been an influence which prompted the addition of the requirement. A skirmish which

117 See In re Carrer (1944) 65 Cal. App. (2d) 681, 151 P. (2d) 164; Smith v. Smith, supra note 86.

118 In re Bullock (1934) 139 Cal. App. 664, 668, 34 P. (2d) 769, 771.

* LL.B., University of California, 1949.

14 Tiffany, Real Property (3d ed. 1939) § 1133.

2 The ordinary statutes do not in terms impose any requirements as to the character of adverse possession, but the courts have established certain requirements in order to protect the interests of the rightful owner. In general, the possession must be actual, visible, exclusive, hostile and continuous during the time specified to create a bar under the statute of hmitations. 4 TrFeANY, op. cit. supra note 1, §1135; 2 C. J. 50.

$3 \mathrm{ml}$. Stats. 1872 , p. 257 . The requirement was added by other jurisdictions in: Colo. Laws, 1874, p. 177; Cal. Amendments to the Codes 1877, p. 99 ; Texas, Acts 1879, p. 132 ; Idaho Gen. Laws 1880-1881, p. 29 ; Utah Laws 1884, p. 186; Nevada Laws 1887, p. 111; So. Dak. Laws 1891, p. 78; Wash. Laws 1893, pp. 20-21; New Mexico Laws 1899, p. 133; Maine Laws 1907, c. 117, p. 131; No. Dak. Laws 1899, c. 158, p. 230; Minn. Laws 1913, c. 239; Mont. Laws 1917, c. 3, p. 2 ; Indiana Stats. 1927, p. 119; Fla. Stats. 1939 , pp. 493-496. 
occurred among legal writers in Indiana following the enactment of the Adverse Possession Act of 1927 lends support to this theory. A critic of the legislation characterized it as the result of an endeavor on the part of assemblymen, provoked by squatter tactics, "to halt the pernicious effect of one person holding color of title and consistently paying taxes and special assessments on land, while another enjoyed the usufruct and, eventually, became seized with title through adverse possession." 4 Proponents of the Act claimed its benefits to be that it afforded security and certainty of titles and removed from the field of litigation a fertile source of controversy."

Whatever may have been the causes for the addition of this requirement, the benefits derived therefrom are uncertain, the legislative purpose difficult to determine, and the effect unfortunate and anomalous in view of the policy underlying adverse possession. ${ }^{6} \mathrm{Di}$ versity in the statutes contaiming the requirement and inconsistency of interpretation by the courts have resulted in divergence in application and indicate a need for statutory changes to prevent undesirable results.

\section{The Purpose of the Requirement:}

The object of conditioning the acquisition of title by adverse possession upon the payment of taxes during the statutory period is not clearly indicated in legislation or decisions. ${ }^{7}$ One logical result has been to encourage persons to make payments of taxes, and this was held to have been the legislative intent of the enactment by the South Dakota court. ${ }^{8}$ This view has also been expressed in California, Illinois and Texas decisions. ${ }^{9}$ The Illinois court later changed its view

4 Farabaugh and Amold, Commentaries on the Public Acts of Indiana, 1927-II. The Adverse Possession Act (1928) 4 IND. L. J. 112. The authors criticize the legislation as demonstrating the danger of legislation designed to meet a specific situation without carefully scrutinizing its possible effects.

5 Gavit, In Defense of the Intdiana Adverse Possession Act of 1927 (1929) 4 IND. L. J. 321 .

6 Ballantine, Titles by Adverse Possession (1918) 32 HARv. L. Rev. 135, states: "The statute has not for its object to reward the diligent trespasser for his wrong nor yet to penalize the neghigent and dormant owner for sleeping upon his rights; the great purpose is automatically to quiet all titles which are openly and consistently asserted, to provide proof of meritorious titles, and correct errors in conveyancing."

7 Generally the requirement has been added as an amendment to existing statutes of limitation for real property or under the general title "Limitations." See session laws cited supra note 3 .

8 Murphy v. Nelson (1905) 9 S. D. 197, 102 N. W. 691. The court based this conclusion in part upon the fact that the title of the legislation was "An Act Declaring the Effect of Continued Payment of Taxes on Land Held under Color of Title."

9 McDonald v. McCoy (1898) 121 Cal. 55, 53 Pac. 421; Cofield v. Furry (1857) 19 III. 183; Dutton v. Thompson (1892) 85 Tex. 115, 19 S.W. 1026. A later California opinion stated that payment alone was not the purpose, but that the intent was that the payment be made by the claimant. See McNoble v. Justiniano (1886) $70 \mathrm{Cal} .395$, 11 Pac. 742. 
and declared that the object "manifestly" was to protect bona fide purchasers and to evidence the good faith of the claimant. ${ }^{10}$ California and Texas decisions also suggest that the payment of taxes by the claimant evidences the good faith of the possessor while giving notice of his possession to the true owner. "In view of the fact that five jurisdictions set forth "good faith" as a separate requirement, and seven jurisdictions require color of title which is more indicative of good faith than is tax payment, this reasoning seems of dubious validity. ${ }^{12}$ The efficacy of the tax payments as notice to the true owner is slight in comparison to that given by actual possession of the land, or by recordation of the instrument giving color of title. ${ }^{13}$

The Montana court has offered the unique suggestion that the purpose of the requirement is to protect the holder of the legal title against "clandestine" encroachments by strangers, ${ }^{14}$ although how an encroachment could be considered "clandestine" if it fulfilled the other requirements of the Montana limitation statutes is difficult to imagine. ${ }^{15}$ The immediate reason for the addition of the requirement in Indiana apparently was to prevent "squatters" from obtaining title to corporation-owned lands, ${ }^{16}$ but the courts have not interpreted the statute in any significant situation or attempted to state its objectives. ${ }^{17}$

The most credible explanation offered for the inclusion of the requirement is that it is peculiar to jurisdictions which have short periods of limitation for actions involving real property. ${ }^{18}$ The history of the Illinois statute seems to give weight to this explanation. In 1839, Illinois established a seven year period of limitation for actions against claimants to land under connected legal or equitable titles given by the state or the United States pursuant to the authority to

10 Rawson v. Fox (1872) 65 III. 200. A similar view was expressed by the Tenth Circuit Court of Appeals in applying the Pueblo Lands Act, 25 U.S. C. A. $\$ 331$ and NEtv MEX. STaTs. (1941) $\S 27: 121$ in United States v. Wooten (C. C.A. 10th 1930) $40 \mathrm{~F}$. (2d) 882.

11 McDonald v. McCoy, supra note 9; Cavanaugh v. Jackson (1893) 99 Cal. 672, 34 Pac. 509; Dutton v. Thompson, supra note 9; Witchita Valley R. Co. v. Somerville (1915) (Tex. Civ. App.) 179 S. W. 671.

12 See Chart I, infra.

13 Cavanaugh v. Jackson, supra note 11; Dutton v. Thompson, supra note 9. $C f$. Note (1948) 1 U. OF FIA. L. REv. 291 stating that the requirement is undoubtedly sound as giving the true owner notice that an adverse possessor has arrived on the scene.

14 Bearmouth Placer Co. v. Passerell (1925) 73 Mont. 306, 311, 236 Pac. 673, 675.

15 MONT. REv. CODE 1935 , c. $26, \$ \S 9015-9024$ list detailed requirements for adverse possession including occupation, possession, cultivation and inclosure.

10 Articles cited supra notes 4 and 5.

17 Sheets v. Stiefel (1947) 117 Ind. App. 584, 74 N. E. (2d) 921 ; Cooper v. Tarpley (1942) 112 Ind. App. 1, 41 N. E. (2d) 640; and Marengo Cave Co. v. Ross (1937) 212 Ind. 624,10 N. E. (2d) 917 do not discuss the purposes.

18 Streeter Co. v. Fredrickson (1902) 11 N.D. 300, 91 N.W. 692. Note (1932) 20 CALIE. L. REv. 432, 433. 
sell land for taxes. The purpose of this statute was to give security to tax titles, which, by reason of abandonment by settlers, had become common. The statute of 1839 was strictly construed by the courts, and as a result discrepancies based on procedural inaccuracies prevented perfection of title by deserving claimants. To remedy this situation, the Act of 1872 accorded the protection of the seven year statute to persons in possession of land with color of title in good faith who paid all taxes assessed thereon for the statutory period. ${ }^{10} \mathrm{How}$ ever, it is noteworthy that in the jurisdictions with the tax requirement the periods of limitation vary from five to twenty years, ${ }^{20}$ while four jurisdictions which do not require the payment of taxes have seven year statutes applicable to certain situations, and eleven jurisdictions have ten year statutes. ${ }^{21}$ It is not, therefore, universally considered an essential requirement for periods of limitation of less than the classic twenty years. ${ }^{22}$

In Alabama and Arkansas, where the payment of taxes by claimants of title by adverse possession has significance other than evidentiary, the effect of the statutory requirement seems to bear a more direct relation to the stated purposes. In Alabama, the adverse claimant must have color of title, duly recorded, and must annually list the

192 Dembitz, LaNd Titzes (1895) $\$ 186$.

20 Five years: ArIz. Code (1939) 29-102, 29-104; Calif. Code Crv. Proc. $\$ \S 321$ 325; Idafo Code (1947) 5-210; Nev. Comp. LAws (Supp. 1931-1941) \$ 8517; Tex. StaTs. (Vernon's 1948) Title 91, Art. 5509.

Seven years: Colo. Stats. ANN. (1935) c. 40, \$143; Fua. STats. (1941) $\$ \$ 95.16$, 95.18; IrL. Rev. Stats. (1943) c. 83, §§ 6, 7 ; UTAR Code ANN. (1943) § 104-2-12; WasH. REV. STATS. (Remington, 1932) $\$ \$ 788,789$.

Ten years: Mont. Rev. Codes (1935) c. 26, § 9024; N. MEx. Stats. (1941) § 27:121; N. D. REv. Code (1943) § 47-0603; S. D. CoDE (1939) §33.0228.

Fifteen years: MinN. STATS. (1941) $\$ 541.02$ (the tax payment requirement extends to only five of the fifteen years).

Twenty years: Ind. Stats. ANs. (1933) § 2-602(6); Me. Rev. StATS. (1944) c. $160, \S 16$.

2I Seven years: GA. CODE (1933) \$ 85-407 (when claimant has written evidence of title); N. C. CODE (1943) \$1-38 (when possessor has color of title); Pens. Stats (Purdon, 1936) c. 12, $\$ 71$ (when claimant's entry was with equitable right); Tress. COJE (Williains, 1934) $\$ \$ 8582-8584$.

Ten years: Iowa Code (1946) $\$ \S 614.1,560.2$; LA. Crv. Code (1945) $\S 3479$; MxcII. Compr. Laws (1929) § 13964 ; Miss. Code (1942) § 711 ; Neb. Rev. Stats. (1943) § $25-$ 202 ; R. I. GeN. LAws (1938) c. $438, \S 2$; S. C. Cone (1942) §375; VA. CoDE (1936) $\S 5805$; W. VA. Code (1943) §5393; WIS. Stats. (1943) \$330.02; Wxo. Rev. Stats. (1931) \$ 89-406.

22 Foster, Nebraska Law of Adverse Possession (1944) 23 NEB. L. REv. 1 questions the evidentiary value of tax payments by an adverse clainant, stating that the only thing an adverse possessor recognizes when lie pays taxes is the taxing power of the state.

The opinion of the judiciary as to the necessity of the requirement ranges from the Montana court's refusal to question either the power of the legislature to include it, or its wisdoin, Bearmouth Placer Co. v. Passerell, supra note 14, to the blunt statement of the California court in Cavanaugh v. Jackson, supra note 11 at 674,34 Pac. at 509 that "We see no great recessity for the enactment of the provision in the first instance." 
land for taxation, if it is subject thereto. ${ }^{23}$ The purpose of this requirement is to enable the true owner to ascertain what land is intended to be held and claimed by the adverse possessor. ${ }^{24}$ In Arkansas, unimproved or uninclosed land is deemed to be in the possession of the person who pays taxes thereon for seven years if he has color of title, ${ }^{25}$ and the payment of taxes on wild and unimproved land for 15 years creates a presumption that the person so paying has color of title, and that the payments were made under color of title. ${ }^{26}$ The general statute of limitation requiring seven years adverse possession ${ }^{27}$ may thus operate in favor of an adverse claimant who is not in actual possession and who does not have color of title, but who has consistently paid taxes for fifteen years. The legislation which introduced this system was entitled "An Act for the protection of those who pay taxes on land." 28 Declaring that the right of the state to have its taxes promptly paid is as important as the right of the individual to be protected in his property, and that the person claiming to be the real owner can prevent loss of his property by paying taxes, or by taking possession of and improving the land, the courts have held that the purpose of the legislation is to encourage the payment of taxes and protect those who pay them. ${ }^{29}$ In adverse possession situations in these jurisdictions, the payment of taxes requirement does not burden the adverse claimants. ${ }^{30}$ In jurisdictions where tax payment is an essential element of adverse possession, it is often the cause of defeating an otherwise meritorious claim. ${ }^{31}$

\section{Diversity in Statutory Terms:}

The variations in the terms of the statutes and in the circumstances in which they apply are illustrated in the accompanying charts.

23 ALA. CODE (1940) tit. 7, $\$ 828$. The claimant may quahify otherwise by having duly recorded color of title or claim by descent or devise from a predecessor who was in possession. The statute is expressly mapplicable to cases involving boundary questions. See discussion in Bradley v. Gordon (1941) 240 Ala. 556, 200 So. 736.

24 McCraw v. Lindsey (1923) 209 Ala. 214, 216, 95 So. $898,900$.

25 ART. STATS. (1947) \$37-102.

20 ART. STATS. (1947) $\$ 37-103$.

2T ARK. STATS. (1947) §37-101.

28 Ark. Acts (1899) LXVI, p. 117.

20 Schmeltzer v. Scheid (1941) 203 Ark. 274, 157 S. W. (2d) 193 ; Towson v. Denson (1905) 74 Ark. 302, 86 S. W. 661. See also discussion in Hubble v. Grimes (1947) 211 Ark. 49, 199 S. W. (2d) 313.

30 Alabama: McCraw v. Lindsey, supra note 24 (unintentional mistake in describing the land for assessment did not bar the claimant).

Arkansas: Anderson-Tully Co. v. Murphree (C. C.A. 8th 1946) 153 F. (2d) 874 (adverse claimant who had paid taxes on area which included site of an island formed in the Mississippi River for the statutory period prevailed over state's claim under legislation regarding newly formed islands). See also: Koonce v. Woods (1947) 211 Ark. 440, 201 S. W. (2d) 748; Jones v. Brown (1947) 211 Ark. 164, 199 S.W. (2d) 973; Rachels v. Stecher Cooperage Works (1910) 95 Ark. 6, 128 S. W. 348.

31 Discussed infra. See also Comment (1932) 20 CALIF. L. Rev. 432 ; Note (1941) 1.32 A. L. R. 213. 
Chart I. Statutes requiring payment of taxes as an element of adverse possession.

\section{REQUIREMENTS}

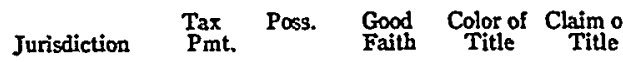

*Arizona

Code 1939

§ 29-102

§ 29-104

$x \quad x$

$\mathbf{x}$

$x$

$x$

$x$

Duly recorded deed

Recorded deed 1

Applies only to town

and city lots

\section{* Carlfornia}

Code Civ. Proc.

$\S 325$

$\mathrm{x}$

$x$

$x$

5

COLORADO

Stats. 1935

C. $40, \S 143$

C. $40, \S 144$

$\frac{x}{x}$

$\mathbf{x}$

$\begin{array}{ll}x & x \\ x & x\end{array}$

x

Applies only to vacant and unoccupied lands. Can be defeated by tax payment by person with better title

\section{*FIORIDA}

Stats. 1941

$\S 95.16$

$\mathbf{x}$

x

$x$

Return of property for assessment by proper legal description

$\S 95.18 \quad x \quad x$

$x$

Return of property for assessment by proper legal description

Period of
Limitation
(years)
(years)

\section{$\$ 95.18$}

$x$

*IDAHO

Code 1947

\& 5-210

$x \quad x$

$x$

\section{IILENoIS}

Rev. Stats. 1943

C. $83, \S 6 \quad x$

C. $83,87 \quad x$

$\mathrm{x}$

x $x$

$\mathbf{x}$

Applies only to vacant and unoccupied lands. Can be defeated by tax payment by person with better title

\section{*INdiana}

Stats. 1946

\$3-1314 $x$ x

Claimant must lave paid taxes during the period he claims to have been in possession

MaIne

Stats. 1944

C. $160, \S 16$

$\mathrm{x}$

$x$

$\boldsymbol{x}$

Recorded deed. Applies 20 to uncultivated land in incorporated places. 


\section{REQUIREMENTS}

Jurisdiction Tax $\underset{\text { Pmt. }}{\text { Poss. }} \underset{\text { Faith }}{\text { Good }}$ Title Claim of

* Minnesota

Stats. 1941

8 541-02

$x \quad x$
Other $\quad \begin{gathered}\text { Period of } \\ \text { Iimitation } \\ \text { (years) }\end{gathered}$

Not applicable to

15

boundary cases or lands not assessed for taxation. Payment of taxes is required for only five consecutive years

* Montana

Rev. Codes 1935

C. $26,89024 \mathrm{x}$

$x$

$x$

\section{* NEVADa}

Comp. Laws 1929

Supp. 1931-1941

$\$ 8517(18) \times x$

$\mathbf{x}$

Tender of payment of 5 taxes will suffice

*New Mexrco

Stats. 1941

$\begin{array}{llllll}\$ 27: 121 & x & x & x & x\end{array}$

\section{North Dakota}

Rev. Code 1943

\$47-0603 $x$ X

SOUTH DAKOTA

Code 1939

$\begin{array}{llllll}\$ 33.0228 & x & x & x & x & x \\ \$ 33.0229 & x & & x & x & x\end{array}$

Applies to vacant and 10 unoccupied land

\section{Texas}

Stats. 1936

Title 91,

Art. $5509 \quad x$

x

$\mathrm{x}$

Duly registered deed 1

5

*Utart

Code 1943

$\$$ 104-2-12 $\quad \mathrm{x} \quad \mathrm{x}$

WaShIngton

Rem. Rev. Stats. 1932

$\begin{array}{llllll}8788 & x & x & x & x & x \\ 8789 & x & & x & x & \end{array}$

Notes:

* Indicates that the tax payment requirement is applicable to all situations wlere title is claimed by adverse possession, except as noted herein, or in Chart II, infra.

1. Statute cannot benefit one claiming through a forged deed or forged power of attorney.

2. No statutory period is stated. General limitation period for real property given. 
CharT II. Alternative statutes of limitation without a tax payment requirement.

Jurisdiction $\begin{gathered}\text { Period of } \\ \text { Limitation } \\ \text { (years) }\end{gathered}$

Stats. 1935

C. $40, \S 136$

IlLiNors

Rev. Stats. 1943

C. $83, \S 1$

MaINe

Stats. 1944

C. $160, \$ 1$

NEvada

Comp. Laws 1929

Supp. 1931-1941

\$ 8508 (9)

New Mexico

Stats. 1941

\$27-120

Norta Dakota

Rev. Code 1943

§ 28-0104

South Dakota

Code 1939

§33.0217

TExas ${ }^{1}$

Stats. 1936

Title 91, Art. 550 ?

Title 91, Art. 5510

Title 91, Art. 5519

WASHINGTON

Rem. Rev. Stats. 1932

$\S 786$

$\$ 156$

Notes:

1. See West, The Texas Three Year Statute of Limitations (1941) 19 TEx. L. Rrv. 375 for discussion of the Texas statutes.

\section{Effect of the Requirement in Disputed Boundary Situations:}

In a recent Florida case, defendants in a quiet title action relied upon adverse possession to establish their right to a strip of land which had been inclosed with the property described in their deed by fences maintained from thirty-three to forty-five years. Defendants had been in possession for nine years and had paid the taxes assessed on their lot. Since taxes in the area were assessed by lot number, and the legal description of defendants' deed did not include the land in controversy, it was held that they had not complied with the statute which 
made payment of taxes for seven years an essential element of adverse possession. ${ }^{32}$ This result, the first decision of a boundary dispute arising since Florida added the payment of taxes requirement, is a typical example of the inequities which arise in the disputed boundary situations in jurisdictions having the tax requirement. In the majority of jurisdictions in the United States, if the true boundary line as determined by survey does not correspond to the line established by occupation and erection of buildings, fences and other structures, the problem may be solved by application of the doctrine of agreed boundaries, principles of estoppel, or the title may be found to have been acquired by the occupant by adverse possession, and thus the practical location may prevail. ${ }^{33}$ But, in the jurisdictions requiring the adverse claimant to have paid all taxes for the statutory period, the occupant in such a situation is precluded from prevailing by adverse possession, since assessment of taxes is normally made with reference to the deed of the taxpayer, and thus the area between the deed line and the line of occupancy cannot be held to have been taxed to the claimant. Thus, unless he can bring his case within the requirements of the agreed boundaries rule, or establish an estoppel against the true owner, he cannot obtain title to such a disputed strip. This view, consistently followed by the California courts since the addition of the tax payment requirement in $1872,{ }^{34}$ was sharply criticized when first applied to defeat the defense of adverse possession, by a dissenting justice who believed that the tax requirement should not be applicable to the disputed boundary situation. ${ }^{35}$ In an early Utah case, the court

32 Palmer v. Greene (1947) 159 Fla. 174, 31 So. (2d) 706. Although defendants' predecessors presumably could have established title by adverse possession prior to the addition of the tax payment requirement, such title had not been established by the evidence.

332 TrFany, $\$$ 653-656; 4 TIFFANy, $\$ 1159$, both op. cit. supra note 1 . For the doctrine of agreed boundaries to apply, the true lime must be uncertain or in dispute, and the parties must agree that a selected line will be regarded as the true line. The agreement may be express, or implied from acquiescence, and must be followed by possession in accordance therewith. Estoppel may be applied when there is no agreement, but the owner has recognized a hine as the boundary and the claimant has made improvements with reference to that line, even when the owner was ignorant of or mistaken as to the true line. Some jurisdictions require knowledge on the part of the owner that the line indicated is not the true line. See also: Loeb, The Establishment of Boundary-Lines by Practical Location (1916) 4 CalIF. L. REv. 179; Comment (1932) 20 CaIIF. L. REv. 430,433 , note 3 .

34 Staniford v. Trombly (1919) 181 Cal. 372, 186 Pac. 599; Friedman v. So. California T. Co. (1918) 179 Cal. 266, 176 Pac. 442; Fitzimons v. Atherton (1912) 162 Cal. 630, 124 Pac. 250; Mann v. Mann (1907) 152 Cal. 23, 91 Pac. 994; Eberhardt v. Coyne (1S96) 114 Cal. 283, 46 Pac. 84; McDonald v. Drew (1893) 97 Cal. 266, 32 Pac. 173; Johnson v. Buck (1935) 7 Cal. App. (2d) 197, 46 P. (2d) 771; Wilder v. Nicolaus (1920) 50 Cal. App. 776, 195 Pac. 1068.

$35 \mathrm{McD}$ onald v. Drew, supra note 34, McFarland, J. concurring, $97 \mathrm{Cal}$. at 270, 32 Pac. at 173. See also Justice McFarland's criticism in Eberhardt v. Coyne, supra note 34 at 287,46 Pac. at 85 . 
indicated that absent evidence to the contrary, a claimant whose adverse possession was in accord with the statute in other respects, might be "presumed" to have paid the taxes on the disputed strip in the boundary situation. ${ }^{36}$ In the first boundary dispute arising after the addition of the tax requirement by Idaho, the court was able to hold for the claimant on the basis of a fortunate error in the original survey. By mistake, the disputed strip had been included within the boundaries of the claimant's lot due to mislocation of the original monuments. Although this error was later rectified, assessments were made and paid according to lot number, with reference to the original monument. Thus, the court found that the claimant, having paid taxes according to his lot number, had paid the taxes assessed against the disputed strip and perfected title thereto. ${ }^{37}$ Regrettably, the fortunate error was not repeated, and the dictum of the Utah court was ignored and subsequent decisions in Idaho and Utah, as well as in Nevada, follow the California view. ${ }^{38}$

In those jurisdictions where alternative statutes providing for a longer period of adverse possession with no tax payment requirement are available to the claimant, it is possible to avoid the harsh result when the occupation is of long standing. ${ }^{38}$ When the statute requires possession with color of title and payment of taxes to concur for the limitation period, the lack of "paper title" to the disputed strip in boundary cases would of itself ordinarily prevent the adverse claimant from qualifying. ${ }^{40}$ However, in a Washington case, a claimant purchased property in the belief that it ran to a fence which was subsequently found to be located five feet over on the next lot. The requisite

38 See Crane v. Judge (1905) 30 Utah 50, 83 Pac. 566. Defendant's claim of title by adverse possession was defeated in this instance by a stipulation that the plaintiff had paid all taxes on the disputed strip and defendant was held to have acquired only an easement for his building which projected thereon.

37 Bayhouse v. Urquides (1909) 17 Idaho 286, 105 Pac. 1056.

38 Balmer v. Pollak (1947) 67 Idaho 494, 186 P. (2d) 217; Meyer v. Schoeffler (1924) 39 Idaho 500, 227 Pac. 1061 ; Blayden v. Morris (1923) 37 Idaho 37, 214 Pac. 1039; Brown v. Brown (1910) 18 Idaho 345, 110 Pac. 269; Malouf v. Fischer (1945) 108 Utah 355, 159 P. (2d) 881 ; Peterson v. Johnson (1934) 84 Utah 89, 34 P. (2d) 697; Tripp v. Bagley (1928) 74 Utah 57, 276 Pac. 912; Coop v. George A. Lowe Co. (1927) 71 Utah 145, 263 Pac. 485 ; Small v. Robbins (1912) 33 Nev. 288, 110 Pac. 1128 (decision was for the claimant on grounds of acquiescence and estoppel. A dissenting opinion points out that inasmuch as the judgment below was based upon adverse possession, which could not be supported since the taxes had not been paid by the claimant, and there was no showing in the record of a finding of acquiescence or estoppel, the majority opinion while purporting to follow the California rule, was erroneous).

39 See Chart II, supra.

40 See Chart I, supra. Denver Co. v. Colorado Co. (1914) 58 Colo. 313, 145 Pac. 707 ; Nilson Bros. v. Kahn (1924) 314 Ill. 275, 145 N. E. 340; Miller v. O'Leary (1906) 44 Wash. 172, 87 Pac. 113 ; Hesser v. Siepmann (1904) 35 Wash. 14, 76 Pac. 295. See also Ward v. Rodriguez (1939) 43 N.M. 191, 88 P. (2d) 277 which raises the problem but avoids meeting the issue by holding the possession not adverse on other grounds. 
color of title was present in this case since claimant had secured a quit-claim deed to the disputed strip from his grantor in addition to the deed to the main lot. ${ }^{41}$ The court held that adverse possession had been established and the tax requirement fulfilled despite the fact that taxes were paid according to the deed description. The court reasoned that it was more probable that the assessment was made, and the value of the property set "... as it appeared upon the ground than that he [the assessor] viewed and valued it according to the true lot lines." 42

It has been argued that the fact that adverse possession is made unavailable to a deserving occupant in the disputed boundary situations is not of great importance; that if there is a bona fide dispute as to the true line, the doctrines of agreed boundaries and estoppel are available, and inasmuch as surveying methods have greatly improved, there is little likelihood that such encroachments will occur innocently. ${ }^{43}$ However, elements of estoppel may be lacking, and conditions preventing the application of the doctrine of agreed boundaries may be present, ${ }^{44}$ leaving the occupant without redress. The fact that such cases have arisen in recent years ${ }^{45}$ and the situation existing in some communities where land titles still are dependent upon old maps which may contain inaccuracies ${ }^{40}$ would seem to answer this argument. The problem was recognized and met in Minnesota by express statutory exception of the boundaries disputes from the tax payment requirement. ${ }^{4 \pi}$

\section{Effect of the Requirement in Cases of Mistake in Description or Error in Assessment:}

It is essential to compliance with the statutes in all jurisdictions that the payment of taxes be made on the particular land claimed ad-

41 King v. Bassindale (1923) 127 Wash. 189, 220 Pac. 777.

42 Id. at 192, 220 Pac. at 779.

43 Gavit, op. cit. supra note 5.

44 2 TIFFANY, op. cit. supra note $1, \S 656$ and cases cited supra note 11 indicate estoppel will not operate in some jurisdictions when the person sought to be estopped is ignorant of the true line. In Note (1930) 69 A. L. R. 1430 it is pointed out that the law of agreed boundaries and acquiescence is in a chaotic condition and that it is difficult definitely to ascertain the circumstances under which it will be applicable.

45 Palmer v. Greene (1947) supra note 32 ; Balmer v. Pollak (1947) supra note 38; Malouf v. Fisher (1945) supra note 38; Johnson v. Buck (1935) supra note 34.

46 Loeb, op. cit. supro note 33 points out that the original survey of Los Angeles, California ("Ord's Map") does not "locate itself on the ground," no monument of the original survey having survived. Yet almost every description used in conveying property in the most congested part of the city refers to and is dependent upon "Ord's Map."

47 Minn. Stats. 1941, $\$ 541.02$. "These provisions shall not apply to actions relating to the boundary line of lands, which boundary hines are established by adverse possession ...." The courts have held in favor of claimants by adverse possession in the boundary dispute cases. Mellenthin v. Brantman (1941) 211 Minn. 336, 1 N. W. (2d) 141; Skala v. Lindbeck (1927) 171 Minn. 410, 214 N. W. 271; Riley v. Kump (1927) 
versely. ${ }^{48}$ It is not enough that the claimant makes a payment in the belief that he is paying on the claimed land ${ }^{49}$ Situations arise in which the claimant's compliance is questioned, because, although the payments have in fact been made, the description on the assessment rolls does not agree with that contained in the claimant's deed, or with the area actually occupied.

The Supreme Court of California was faced with an interesting problem in the recent case of Sorensen v. Costa $a^{50}$ which arose out of a general mistake as to the proper description of several lots in one city block. For over 40 years, plaintiff and his predecessors had occupied a house situated on the west half of Lot 7 , upon which they paid taxes, believing it to be the property described in their chain of title as the east half of Lot 7 . During the same period, defendant occupied the east half of Lot 7, believing it to be the property described in his deed as the west half of Lot 8 . At a tax sale, defendant purchased the east half of Lot 8, which led to the discovery of the confusion of titles. The actual boundaries of all the lots in the block were one-half a lot's width to the west of the land described in the deeds of the occupants, so that if one claimant's defense of acquisition of title by adverse possession were to fail, the titles of all would be clouded and subject to defeasance. The trial court's judgment quieting title in plaintiff was upheld by the court against the contention of defendant that the payment of taxes requirement had not been met since the taxes paid by plaintiff were assessed according to the deed description. The court held that the evidence showed the land as assessed and as occupied by plaintiff was improved property, whereas the description in plaintiff's deed and on the tax rolls referred to unimproved property. Thus, the court reasoned, the description on the tax rolls was mistaken and plaintiff and his predecessors had in fact paid taxes actually assessed against the improved land which they occupied.51

It would seem that the fortuitous circumstance that the land actually described in the claimant's deed and on the tax rolls in the instant case was a vacant lot aided the court in holding that plaintiff

170 Minn. 58, 212 N. W. 13; Frederickson v. Fenke (1926) 167 Minn. 356, 209 N.W. 257; Kelley v. Green (1919) 142 Minn. 82, 170 N. W. 922.

48 Note (1941) 132 A. L. R. 213 and cases cited therein.

49 Standard Quicksilver Co. v. Habishaw (1901) 132 Cal. 115, 64 Pac. 113; Reynolds v. Willard (1889) 80 Cal. 605, 22 Pac. 262; Citizens Right of Way Co., Ltd, v. Ayers (1919) 32 Idaho 205, 179 Pac. 954; Citizens Right of Way Co., Ltd., v. Pollard (1919) 32 Idaho 212, 180 Pac. 259; Pinchback v. Hockless (1940) (Tex. Civ. App.) 137 S. W. (2d) 864 ; Sharpe v. Kellogg (1909) 53 Tex. Civ. App. 543, 116 S. W. 401.

50 (1948) 32 Cal. (2d) 444, 196 P. (2d) 900.

51 The district court of appeal had reversed the finding of title by adverse possession in plaintiff as unsupported by the evidence, holding that the plaintiff had in fact paid taxes on the east half of Lot 7 , which was a vacant lot. Sorensen v. Costa (1947) 187 P. (2d) 472,473 . 
had proved by substantial evidence that the description was mistaken and in reaching a just result. Previous decisions had established that for purposes of assessment, a description of the land was sufficient if it enabled the owner to identify the property without being misled thereby. ${ }^{52}$ The court could thus deny defendant's contention that the description on the tax rolls should be controlling, inasmuch as he did not and could not show that he was misled to his injury, since during the time of adverse possession he did not know that he had any claim to the land occupied by plaintiff, and had in fact paid taxes on land he was occupying which were assessed under a similar mistaken description. ${ }^{63}$

In jurisdictions in which color of title is a concurrent requirement with the payment of taxes, a mistake in description on the part of the assessor might not be overcome so readily. ${ }^{54}$ In a recent Illinois case, an erroneous entry on the property record card included the disputed land, although the claimant's deed description did not. The court held that the deed description controlled so that taxes had not been paid by claimant, but the concurrent ground for denying adverse possession was failure to establish possession with color of title. ${ }^{55}$ Decisions in Texas indicate that, if no one has been misled, minor errors will not prevent compliance with the tax requirement. ${ }^{56}$ Compliance was also found by the Texas court when the metes and bounds description of the claimant's deed included 21.4 acres more than the acreage called for in the deed, although taxes had been assessed in accord with the acreage description. ${ }^{57}$ When the deed description was shown by the monuments and other descriptions to have erroneously included the claimed area, claimant's payment of taxes according to the deed description was held insufficient by the Washington court. Although testimony established that the strip was assessed to plaintiff along with the adjoining land, the decision was justified on the ground that the allegations of the pleadings were not sufficient to justify a claim of adverse possession, and even if they had been, the fact that defendant had requested the assessors to segregate the land and assess it to them prevented the tax payment from giving any character of

52 San Francisco v. San Mateo (1941) 17 Cal. (2d) 814, 112 P. (2d) 595 ; Biaggi v. Phillips (1942) 50 Cal. App. (2d) 92, 122 P. (2d) 619; E. E. McCalla Co. v. Sleeper (1930) 105 Cal. App. 562, 288 Pac. 146; Numitor Gold Min. Co. v. Katzer (1927) 83 Cal. App. 161, 256 Pac. 464; Lummer v. Unruh (1914) 25 Cal. App. 97, 142 Pac. 914.

53 Sorensen v. Costa, supra note 50 at 465,196 P. (2d) at 908.

64 See Chart I, supra. The claimant's color of title may also be found defective due to errors on the part of the assessor. Denver Co. v. Colorado Co. (1914) 58 Colo. 313, 145 Pac. 707.

65 Cienki v. Rusnak (1947) 398 Ill. 77, 75 N.E. (2d) 372.

60 Brabson v. Brownfield (1924) (Tex. Civ. App.) 259 S. W. 251; W. D. Cleveland \& Sons v. Smith (1913) (Tex. Civ. App.) 156 S. W. 247.

or Starkey v. MeNay (1937) (Tex. Civ. App.) 103 S.W. (2d) 1051. 
title to plaintiff. ${ }^{58}$ In the same jurisdiction, an error in platting was held fatal to the claimant when taxes were paid according to the erroneous plat. 59

In several jurisdictions where an alternative statute with a longer period without a tax payment requirement is available the problems arising from misdescription or erroneous assessment may be solved equitably, as in the boundaries situations, if the possession has continued for the requisite number of years. ${ }^{e 0}$ The Florida statutes requiring " . . a return . . by proper legal description ..." would probably by their terms prevent the court from reaching the result achieved by the California court. ${ }^{61}$

The Sorensen v. Costa situation, although not likely to recur frequently, is indicative of inequities which may result from the retention of the tax requirement in its present form. Alabama has obviated this problem by including an exception in the statute requiring the listing for taxation of property claimed adversely: “ . . . an inadvertent failure to list the land for taxation, or any unintentional mistake in the description of the assessment, or unintentional omission of any part of it from the assessment, during the period of ten years, shall not bar the party of his action or defense on his adverse possession." 02 Under this statute, where land was listed by various descriptions during the statutory period, but each assessment placed it in the proper block showing the indicated width, adverse possession was upheld. ${ }^{.3}$

What Constitutes "Payment of Taxes": Double Payment Situations:

Another issue is what payinent made by the adverse claimant is sufficient to meet the terms of the statute. If the taxes have become delinquent during the statutory period, several states hold that the subsequent payment will not satisfy the requirement. .of $^{\text {California fol- }}$ lows this view when the delinquent payment is not made during the period of the claimed adverse possession. ${ }^{65}$ When the delinquent pay-

58 Austrian American Benev. Cemetery Assn. v. De Desrochers (1923) 124 Wash. 179, 214 Pac. 3, 216 Pac. 891.

59 Grays' Harbor Commercial Co. v. McCullough (1921) 113 Wash. 203, 193 Pac. 709 (claimant was able to prevail under an alternative statute of limitations requiring a title deducible in law or equity).

60 See Chart II, supra.

61 FLA. StaTs. (1941) $\$ \S 95.16,95.18$. No cases in regard to the problem have heen reported to date.

G2 ALA. CODE (1940) §828.

B3 McCraw v. Lindsey, supra note 24 .

64 Webber v. Wanamaker (1907) 39 Colo. 425, 89 Pac. 780; Cain v. Ehrler (1914) 33 So. Dak. 536, 146 N. W. 694; Turner v. Dinwiddie (1925) (Tex. Civ. App.) 276 S. W. 444; Baker v. Fogle (1919) 110 Tex. 301, 217 S. W. 146; Aggelos v. Zella Mining Co, (1940) 99 Utah 417, 107 P. (2d) 170; Kennedy v. Anderson (1915) 88 Wash. 457, 153 Pac. 319; Tremmel v. Mess (1907) 46 Wash. 137, 89 Pac. 487.

65 Myran v. Smith (1931) 117 Cal. App. 355, 4 P. (2d) 219. 
ment is made within the five year period of occupancy, California holds it sufficient. ${ }^{66}$ In New Mexico a redemption payment at a tax sale $^{\mathrm{Br}}$ and payment of the delinquent taxes prior to suit have been held sufficient compliance. ${ }^{68}$

If both the adverse claimant and the legal owner of the disputed land have paid the taxes, the decisions are in conflict as to whether the claimant has satisfied the statutory requirement. Reasoning that payment of taxes by any person extinguishes the obligation, Illinois decisions have established the rule that the payment prior in time prevails, so that if the legal owner pays first, the adverse claimant can derive no benefit from his payment. ${ }^{69}$ Colorado and Washington hold that payment by the legal owner gives him a superior equity, and the adverse claimant's payment, even though prior in time, is not sufficient. ${ }^{70}$ In Owsley v. Matson, the California Supreme Court resolved a conflict that existed in prior decisions, holding that the adverse claimant's compliance depends only upon a showing that he paid the taxes for the years in question, and that a prior or subsequent payment by the legal owner is of no consequence. ${ }^{\mathrm{TI}}$ The Oresley case involved a double assessment as well as double payment, and for this reason, it is arguable that as to cases of a single assessment but double

${ }^{68}$ Gray v. Walker (1910) 157 Cal. 381, 108 Pac. 278; Owsiey v. Matson (1909) 156 Cal. 401, 104 Pac. 983; Devlin v. Powell (1921) 67 Cal. App. 165, 227 Pac. 231. See discussion, Comment (1932) 20 CarIF. L. REv. 430 at 434.

07 Tumer v. Sanchez (1946) 50 N. M. 15, 168 P. (2d) 96. Prior interpretation in the federal court had beld a redemption payment insufficient. Pueblo de Taos v. Gusdorf (C. C. A. 10th 1931) $50 \mathrm{~F}$. (2d) 721.

68 United States v. Wooten, supra note 10.

69 Morrison v. Kelley (1859) 22 Mll. 609 ; Clayton v. Feig (1900) 188 Mll. 603, 59 N. E. 245; Osborn v. Searles (1895) 156 Ill. 88, 40 N. E. 452; Bolden v. Sherman (1882) 101 IIl. 483; Ross v. Coats (1871) 58 IIl. 53. In Cramer v. Walker (1913) 23 Idaho 495, 130 Pac. 1002, approval of this rule is expressed.

70 Denver Co. v. Doelz (1910) 49 Colo. 48, 111 Pac. 595; Stuart v. Union Pacific (Colo. 1910) 178 Fed. 753; Grays Hlarbor Comm. v. McCullough, supra note 59 (Wash.); No. Pac. Ry. v. Littlejohn (Wash. 1912) 198 Fed. 700; Turner v. Ladd (1906) 42 Wash. 274, 84 Pac. 866.

71 (1909) 156 Cal. 401, 104 Pac. 983. In Cavanaugh v. Jackson (1893) 99 Cal. 672, 34 Pac. 509, a department decision, the court followed this view, but in a concurring opinion, Mr. Justice Harrison stated the belief that the priority rule should be followed. The concurring opinion was followed in Carpenter v. Lewis (1897) $119 \mathrm{Cal}$. 18, $50 \mathrm{Pac}$. 925; Glowner v. de Alvarez (1909) 10 Cal. App. 194, 101 Pac. 432 ; Commercial Natl. Bank v. Schlitz (1907) 6 Cal. App. 174, 91 Pac. 750. Since the Ozosley decision, the rule has been followed consistently: Cummings v. Laughlin (1916) $173 \mathrm{Cal}$. 561, 160 Pac. 833; Kendrick v. Klein (1944) 65 Cal. App. (2d) 491, 150 P. (2d) 955; Pereira Farms Corp. v. Simas (1924) 69 Cal. App. 159, 230 Pac. 976; Bell v. Germain (1910) 12 Cal. App. 375, 107 Pac. 630. In Van Calbergh v. Easton (1917) 32 Cal. App. 796, 164 Pac. 1113, an attempt by the district court of appeal to confine the Cavanaugh-Owsley rule to the overlapping boundary situation was disapproved by the supreme court upon denial of hearing. 32 Cal. App. at 800, 164 Pac. at 1115. 
payment, the priority rule still prevails in California. ${ }^{\mathbf{7 2}}$ Texas is in accord with the Owsley rule. ${ }^{73}$ An early Utah case, without discussion of the point, favored the adverse claimant in a situation where the trial court found payment by the owner to have also been made during the statutory period. ${ }^{\text {it }}$

\section{Conclusion:}

Conditioning the perfection of title by adverse possession upon the claimant's tax payment has resulted in other problems beyond the scope of this discussion. ${ }^{75}$ The materials presented, however, serve to illustrate the incongruity of the requirement. It is submitted that while the elimination of the requirement would be desirable, relief may be secured to deserving claimants in the situations discussed by less drastic measures. This might be done by: (1) making the requirement inapplicable in the disputed boundaries situation; (2) providing that any unintentional mistake in description, or the omission, unknown to the claimant, of any part of the claimed premises from assessment shall not bar the claimant from the benefit of the statute of limitations; (3) providing that tender of payment of the taxes by the claimant will be sufficient compliance.

Moira Deirdre Ford

\footnotetext{
72 Comment (1932) 20 CALIF. L. REv. 430, 437. The writer relies upon a line of cases prior to the Owsley decision which followed the concurring opinion in Cavanaugh, stipra note 71 . In choosing the majority rule of the Cavanaugh case, the court in Owsley stated that it found that rule to be "... most just and most in accord with the spirit and purpose of the statute." $156 \mathrm{Cal}$. at 407,104 Pac. at 985 . Probahly the Owsley rule will prevail even in the single assessment cases, in view of the policy of the statute. Cases subsequent to Owsley, however, have all been double assessment situations. See Cummings v. Laughlin, Kendrick v. Klein, Van Calbergh v. Easton, Pereira Farms Corp. v. Simas, Bell v. Germain, all supra note 71 .

73 Thomson v. Weisman (1904) 98 Tex. 170, 82 S. W. 503.

i4 Dignan v. Nelson (1903) 26 Utah 186, 72 Pac. 936. Dicta in Railway v. Investment Co. (1909) 35 Utah 528, 101 Pac. 586, approved the California cases following the priority rule, stating that California precedents were normally followed in that jurisdiction. Thus, the view that the Utah court will take when it has to meet this issue is difficult to determine.

75 See: Comment (1932) 20 Calif. L. Rev. 432; Note (1918) 7 CalrF. L. Rev. 65; Notes (1941) 132 A. L. R. 216; (1938) 112 A. L. R. 545; (1930) 69 A. L, R. 1417.
} 